Justice, which began operating in 1984, resolves disputes between members and interprets legislation. The SAI has other institutions: Andean Development Corporation (CAF), Latin American Reserve Fund (FLAR), Simón Bolívar Andean University, Andean Business Advisory Council, Andean Labour Advisory Council and various Social Agreements.

Further to the treaty signed by 12 South American countries in May 2008, it is anticipated that the Andean Community will gradually be integrated into the Union of South American Nations.

Official language: Spanish.

Headquarters: Avda Paseo de la República 3895, San Isidro, Lima 27, Peru.

Website: http://www.comunidadandina.org

Email: correspondencia@comunidadandina.org

Secretary-General: Walker San Miguel (Bolivia).

\section{Association of Caribbean States (ACS)}

The Convention establishing the ACS was signed on 24 July 1994 in Cartagena de Indias, Colombia, with the aim of promoting consultation, co-operation and concerted action among all the countries of the Caribbean, comprising 25 full member states and three (now eight) associate members.

Members. Antigua and Barbuda, Bahamas, Barbados, Belize, Colombia, Costa Rica, Cuba, Dominica, Dominican Republic, El Salvador, Grenada, Guatemala, Guyana, Haiti, Honduras, Jamaica, Mexico, Nicaragua, Panama, St Kitts and Nevis, St Lucia, St Vincent and the Grenadines, Suriname, Trinidad and Tobago, Venezuela.

Associate members. Aruba, Curaçao, France (on behalf of French Guiana, St Barthélemy and St Martin), Guadeloupe, Martinique, Netherlands (on behalf of Bonaire, Saba and Sint Eustatius), Sint Maarten, and the Turks and Caicos Islands.

The CARICOM Secretariat, the Latin American Economic System (SELA), the Central American Integration System (SICA) and the Permanent Secretariat of the General Treaty on Central American Economic Integration (SIECA) were declared Founding Observers of the ACS in 1996. The United Nations Economic Commission for Latin America and the Caribbean (ECLAC) and the Caribbean Tourism Organization (CTO) were admitted as Founding Observers in 2000 and 2001 respectively.

Functions. The objectives of the ACS are enshrined in the Convention and are based on the following: the strengthening of the regional co-operation and integration process, with a view to creating an enhanced economic space in the region; preserving the environmental integrity of the Caribbean Sea which is regarded as the common patrimony of the peoples of the region; and promoting the sustainable development of the Greater Caribbean. Its current focal areas are trade, transport, sustainable tourism and natural disasters.

Organization. The main organs of the Association are the Ministerial Council and the Secretariat. There are Special Committees on: Trade Development and External Economic Relations; Sustainable Tourism; Transport; Natural Disasters; Budget and Administration. There is also a Council of National Representatives of the Special Fund responsible for overseeing resource mobilization efforts and project development.

Headquarters: ACS Secretariat, 5-7 Sweet Briar Road, St Clair, PO Box 660, Port of Spain, Trinidad and Tobago.

Website: http://www.acs-aec.org

Email:mail@acs-aec.org

Secretary-General: Alfonso Múnera (Colombia).

\section{Caribbean Community (CARICOM)}

Origin. The Treaty of Chaguaramas establishing the Caribbean Community and Common Market was signed by the prime ministers of Barbados, Guyana, Jamaica and Trinidad and Tobago at Chaguaramas, Trinidad, on 4 July 1973.

Six additional countries and territories (Belize, Dominica, Grenada, St Lucia, St Vincent and the Grenadines, Montserrat) signed the Treaty on 17 April 1974, and the Treaty came into effect for those countries on 1 May 1974. Antigua acceded to membership on 4 July that year; St Kitts and Nevis on 26 July; the Bahamas on 4 July 1983 (not Common Market); Suriname on 4 July 1995.

Members. Antigua and Barbuda, Bahamas, Barbados, Belize, Dominica, Grenada, Guyana, Haiti, Jamaica, Montserrat, St Kitts and Nevis, St Lucia, St Vincent and the Grenadines, Suriname, and Trinidad and Tobago. Anguilla, Bermuda, the British Virgin Islands, the Cayman Islands and the Turks and Caicos Islands are associate members.

Objectives. The Caribbean Community has the following objectives: improved standards of living and work; full employment of labour and other factors of production; accelerated, co-ordinated and sustained economic development and convergence; expansion of trade and economic relations with third States; enhanced levels of international competitiveness; organization for increased production and productivity; the achievement of a greater measure of economic leverage and effectiveness of member states in dealing with third States, groups of States and entities of any description; enhanced co-ordination of member states' foreign and foreign economic policies; enhanced functional co-operation.

At its 20th Meeting in July 1999 the Conference of Heads of Government of the Caribbean Community approved for signature the agreement establishing the Caribbean Court of Justice. They mandated the establishment of a Preparatory Committee comprising the Attorneys General of Barbados, Guyana, Jamaica, St Kitts and Nevis, St Lucia and Trinidad and Tobago assisted by other officials, to develop and implement a programme of public education within the Caribbean Community and to make appropriate arrangements for the inauguration of the Caribbean Court of Justice prior to the establishment of the CARICOM Single Market and Economy. To this end at its 23rd Meeting in July 2002 the Heads of Government agreed on immediate measures to inaugurate the Court by the second half of 2003, although delays meant it was not inaugurated until April 2005. Among the measures adopted was the establishment of a Trust Fund with a one-time settlement of US $\$ 100 \mathrm{~m}$. to finance the Court.

Structure. The Conference of Heads of Government is the principal organ of the Community, and its primary responsibility is to determine and provide the policy direction for the Community. It is the final authority on behalf of the Community for the conclusion of treaties and for entering into relationships between the Community and international organizations and States. It is responsible for financial arrangements to meet the expenses of the Community.

The Community Council of Ministers is the second highest organ of the Community and consists of Ministers of Government responsible for Community Affairs. The Community Council has primary responsibility for the development of Community strategic planning and co-ordination in the areas of economic integration, functional co-operation and external relations.

The Secretariat is the principal administrative organ of the Community. The Secretary-General is appointed by the Conference (on the recommendation of the Community Council) for a term not exceeding five years, and may be reappointed. The Secretary-General is the Chief Executive Officer of the 